\title{
Časové vědomí a Husserlova kritika Brentana ${ }^{1}$
}

\section{Time Consciousness and Husserl's Critique of Brentano}

\author{
Hynek Janoušek \\ Filosofický ústav \\ Akademie věd České Republiky \\ Jilská 1, 11000 Praha 1 \\ $\&$ \\ Filozofická fakulta \\ Univerzita Hradec Králové \\ Rokitanského 62, 50003 Hradec Králové \\ janousek@flu.cas.cz
}

\begin{abstract}
Abstrakt/Abstract
Článek analyzuje původní verzi Husserlovy kritiky Brentanova pojetí časového vědomí, která je obsažena v Husserlových Přednáškách k fenomenologii vnitřního časového vědomí, a Husserlovu snahu vyřšsit Brentanův argument nekonečně nekonečného regresu v rukopisném textu $O$ primární modifikaci paměti. Z Husserlovy kritiky si všímá jen dvou bodů. Za prvé kritiky Brentanova prezentismu, tj. názoru, že časové vědomí je založeno v bodu př́ítomnosti, v němž jsou psychické fenomény, které názor času konstituují, dány současně. Za druhé Husserlovy výtky, že Brentano nepoužívá pro výklad vědomí času schéma počitkový obsah - pojetí počitkového obsahu. Za tímto účelem rekonstruuje text Brentanovu teorii v podobě, v které ji znal Husserl, a vykládá jak Brentanovy důvody pro odmítnutí časové povahy vnitřního vnímání, tak nedořešené problémy Brentanova hlediska. Následně se pokouší dokázat, že Husserl Brentanův prezentismus podcenil a že věcné problémy, které s jeho odmítnutím souvisely, musel řešit zavedením absolutně „kvaziprezentního“ vědomí a odmítnutím schématu obsah - pojetí pro výklad konstituce imanentních časových jednot. Oba zvolené body Husserlovy kritiky Brentana se tak v pozdějších vrstvách přednášek ukazují jako částečně neoprávněné.
\end{abstract}

The article discusses the original version of Husserl's critique of Brentano's concept of time consciousness, which forms a part of Husserl's Lectures on the Phenomenology of the Consciousness of Internal Time. Next, it gives an overview of Husserl's attempt to solve Brentano's argument from the infinitely infinite regress against the consciousness of internal time. Two points of Husserl's critique of Brentano are analyzed. The first point concerns Husserl's critique of Brentano's presentism. Brentano holds that consciousness of time is contained in the time point of the present now, in which psychical phenomena constituting our time consciousness are given simultaneously. The second point concerns the lack of content - apprehension scheme in Brentano's explanation of the time

${ }^{1}$ Tato studie je výsledkem grantu GAČR P401/11/0371 „Apriorní, syntetické a analytické od středověku po současnou filosofii“", realizovaného ve Filosofickém ústavu AV ČR a na Filozofické fakultě Univerzity Karlovy v Praze. 
consciousness. The article reconstructs Brentano's position in the form known to Husserl and explains Brentano's reasons for refusing the internal consciousness of time as well as problems connected with this refusal. An analysis of Husserl's text proves that Husserl underestimated Brentano's presentism and that he was forced to introduce a concept of the absolute time consciousness to solve the problems connected with his refusal of Brentano's position. Since Husserl had to eventually give up the content - apprehension scheme in his explanation of immanent time unities, his original critique of Brentano is shown to be partly unjustified.

\section{Úvod}

V roce 1930 vyšel v časopisu Archive für die Gesamte Psychologie výňatek z korespondence Franze Brentana s pražským profesorem Karlo-Ferdinandovy univerzity Antonem Martym doplněný o část Martyho univerzitních přednášek. Z pozůstalosti těchto myslitelů text vydal další pražský profesor téže univerzity, Oskar Kraus, který jej opatřil názvem Zur Phänomenognosie des Zeitbewußtseins. Podnětem k vydání textu bylo vydání přednášek k vnitřnímu časovému vědomí Edmunda Husserla, které se konaly v roce 1905 , ovšem vydány byly až v roce 1928. Husserlovy přednášky jsou do značné míry výsledkem redakční práce Edith Steinové z let 1917-1919, jejíž podíl na vzniku textu však Husserl v knižním vydání trestuhodně zamlčel. ${ }^{2}$ Husserl sám vydání přednášek inicioval s mnohaletým zpožděním na základě rozhovorů s Martinem Heideggerem, kterému byla také svěřena jejich závěrečná redakce a který je po dohodě s Husserlem opatřil názvem Přednášky $k$ fenomenologii vnitřního časového vědomi. ${ }^{3} \mathrm{~V}$ důsledku této historie je Husserlův text poměrně disparátním celkem, jehož necelá polovina pochází z původního znění přednášek, zbytek však z rozmanitých textů, které vznikaly v následujících obdobích. Část textu z původních přednášek chybí a ten zachovalý není vždy otištěn $v$ chronologickém sledu. Čtenář, který není obeznámen $\mathrm{s}$ rukopisy a dobovou literaturou, bude při četbě pravděpodobně zmaten, nebot' jednotlivé části vydaných přednášek spolu stojí $\mathrm{v}$ napětí, ne-li přímo $\mathrm{v}$ rozporu, a vznikaly $\mathrm{v}$ komunikaci s autory, které oficiální vydání zmiňuje jen okrajově. Naším cílem nebude podávat zde komentář $\mathrm{k}$ Husserlovu inspirativnímu textu, ale zaměřit se $\mathrm{v}$ kontextu celých přednášek na tu část, která vyprovokovala Krausovu odpověd', totiž na Husserlovu kritiku Brentana, jež naplňuje úvodní pasáže Husserlovy knihy. Tato kritika pochází z původních přednášek z roku 1905. Husserl k ní přistupuje kvůli tomu, že Brentanova pozice tvořila původní východisko jeho vlastního pojetí času ${ }^{4}$ a že k nauce

\footnotetext{
${ }^{2}$ Viz Boehm (1964, s. XIX-XXIV).

${ }^{3}$ Husserl (1993, s. 157).

${ }^{4}$ Viz Husserlovy krátké poznámky ve Philosophie der Arithmetik, které se shodují s Brentanovým pojetím času v 80. letech 19. století v Husserl (1891, s. 20-32).
} 
Přednášek se dostal jejím přepracováním. Ani zde nebudeme analyzovat hodnotu Husserlovy kritiky a rozebírat její jednotlivé body a Krausovy odpovědi na ně. Zaměříme se na jeden jediný problém, který se $\mathrm{v}$ této kritice skrývá a jenž si sám Husserl uvědomil až s několikaletým zpožděním a který by, kdyby Husserl nespojoval se svou fenomenologií tak velké systematické naděje, mohl klidně vést $\mathrm{k}$ vyhlášení konce původního fenomenologického projektu. Tento problém má zároveň určitou nadčasovou povahu - již před diskuzí Husserl-Brentano se vynořil $v$ jednodušší podobě $\mathrm{v}$ recepci teorie časového vědomí Williama Jamese ${ }^{5}$ - a vzhledem $\mathrm{k}$ popularitě filosofie mysli, jejíž hlavní proud nebude moci základní časovou povahu vědomí donekonečna ignorovat, lze navíc očekávat nějakou novou formu jeho reprízy. ${ }^{6}$

O co se jedná? Zhruba řečeno jde o otázku, zdali vědomí vnímá plynutí času v jediném časovém bodě, či zda má vnímání času samo časové trvání. S tímto problémem se pojí ještě další související otázka, a sice zdali vědomí existuje jako bod, či zda má časovou extenzi. Toto je původní znění otázky, z něhož v roce 1905 ještě implicitně vycházel i Husserl. Vrat'me se však prozatím na počátek, a sice k Husserlově kritice Brentana, která - což je důležité - patř́ k původní části přednášek z roku 1905 . $^{7}$ Abychom ji mohli zhodnotit, musíme popsat ty body Brentanovy teorie, které pro ni jsou relevantní a které Husserl sám ještě sdílel ve své Philosophie der Arithmetik. Zároveň však načrtneme hlubší systematický kontext Brentanovy teorie, kterého si Husserl zprvu asi nebyl vědom.

\section{Krátké shrnutí Brentanovy teorie časového vědomí}

Husserl vycházel z podoby Brentanovy teorie, kterou znal z Brentanových přednášek k vybraným otázkám z psychologie a estetiky ${ }^{8}$ a z Martyho pražských přednášek ke genetické psychologii z roku 1889 , jejichž opis si pořídil. ${ }^{9}$

\footnotetext{
${ }^{5}$ James (1895), Strong (1896).

${ }^{6}$ Např. reprezentativní výbor textů o filosofii mysli (Chalmers 2002) neobsahuje na svých 650 stranách jedinou zmínku o časové povaze zkušenosti či „reprezentaci“ času.

${ }^{7}$ Původní znění přednášek je zachováno v $\S$ 1-7, 16-17, 19, 30, 32, 41 a zčásti v $§ 7,11,23$, 31 a 33. Viz úvod Rudolfa Berneta k vydání Husserlových rukopisů k vnitřnímu vědomí času, Bernet (1985, s. XXIV). Vydané přednášky ale neobsahují např́klad původní rozsáhlé vyrovnání s Meinongovou teorií časového vědomí (Bernet, 1985, s. XXIV), které jsou otištěny v Husserl (1985, s. 82-97). Jelikož nám jde v článku pouze o jeden rys, totiž o Husserlovu kritiku Brentana a jeho prezentismu, nebudeme toto východisko rekonstruovat $\mathrm{v}$ jeho úplnosti.

${ }^{8}$ Schuhmann (1977, s. 15).

${ }^{9}$ Husserl (1985, s. 37). Šlo o druhou z celkem pěti verzí teorie časového vědomí, které Husserl vypracoval. Vývoj těchto teorií popisuje Chrudzimski (2005) a částečně Chisholm (1981a).
} 
Nejsnáze lze tuto teorii představit klasickým diagramem časového vědomí, jehož varianty se vynořují u většiny Brentanových žáků. ${ }^{10}$

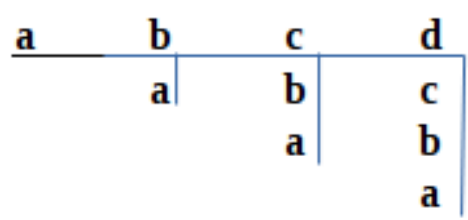

Vodorovná linie představuje posloupnost obsahů (intencionálních předmětů) $\mathrm{v}$ jejich objektivní následnosti. Svislá linie představuje konstituci časového vědomí této následnosti obsahů v tzv. původní asociaci. Podle Brentana patří k mysli podstatně schopnost původní asociace, která kontinuálně reprodukuje a modifikuje každý prvek vnímané následnosti či trvání tak, že je sice podržován v horizontu právě vnímaného, jeví se však jako stále více a více časově „odsunutý“. Vnímáme-li nyní $b$, je $a$ časově modifikováno a připojeno $\mathrm{k} b$ a my vnímáme následnost $a$ - $b$. Vnímáme-li poté $\mathrm{c}$, je $b$ podrženo jako časová hloubka $c$ a $a$ jakožto časová hloubka $b$ kontinuálně klesne $\mathrm{v}$ časové modifikaci tak, že nyní vnímáme posloupnost $a-b-c$. Důležité je, že se zde jedná o konstituci časového názoru posloupnosti. ${ }^{11}$ Posloupnost melodie skutečně slyšíme, posloupnost pohybu skutečně vidíme. Brentano sám nazýval tento fenomén proterestezí, čili následným vnímáním. ${ }^{12}$ Časový názor následného vnímání je však omezený. Fakticky jsme podle Brentana schopni vnímat časovou posloupnost v rámci vteřin či zlomků vteřin. Jakmile obsah v časovém vědomí poklesne pod určitou mez, zcela o svou názornost přichází. Může být sice následně přivolán zpět v pamět’ové rekolekci, sám o sobě je však podle Brentana $\mathrm{v}$ rámci toho, co právě názorně vnímáme, prezentován pouze „,pojmově“, tj. zhruba řečeno na základě pojmy prostředkované sítě relací „před“, „po“, „minulý“, „,budoucí“ apod., které se uskupují „kolem“ názorně daného rozpětí proteresteze. Zatímco $\mathrm{v}$ rámci původní asociace je podržovaný obsah prvkem primární paměti, v oblasti nenázorné paměti se jedná o pamět' sekundární. Rozdíl těchto dvou typů podržování minulého velmi přesně vystihl William James, jehož teorie zdánlivé př́tomnosti (specious present) se právě popsané Brentanově teorii proteresteze $\mathrm{v}$ mnohém podobá.

„Předmět, který si v přísném smyslu slova vybavujeme, je předmět, který ve vědomí zcela scházel a který se nyní znovu obnovuje. Je přinesen, přivolán, takř́ikajíc vyloven z rezervoáru, v kterém byl spolu s nesčetnými dalšími předměty pohřben a v němž se nám ztratil z očí. Předmět primární paměti

\footnotetext{
${ }^{10}$ Tento diagram uvádí ve svých vzpomínkách Carl Stumpf, viz Kraus (1919, s. 136).

${ }^{11} \mathrm{~V}$ případě vjemu trvání by situace byla mutatis mutandis analogická.

${ }^{12}$ Viz Kraus (1930, s. 7).
} 
však není takto přivolán, nikdy se neztratil, jeho chvíle nikdy nebyla odříznuta od chvíle bezprostředně přítomného momentu. Přichází $\mathrm{k}$ nám vlastně jako prvek zpětné části přítomného rozpětí času, nikoliv jako prvek opravdové minulosti.“13

V Brentanově teorii je předmětem primární paměti názorně reprodukovaný a časově modifikovaný intencionální předmět ve smyslu počitkového data (fyzického fenoménu). Brentano však neignoruje ontologický rozměr svého popisu. Jelikož, podle něj, to, co je minulé, již není, nemůže minulý obsah existovat reálně. Časová modifikace právě prezentně vnímaného obsahu v právě uplynulý obsah je tedy pro Brentana přechodem reálného bytí obsahu v obsah ireálný. Totéž platí i pro anticipaci budoucnosti, která je v Brentanově původní teorii produktivní projekcí založenou v paměti. ${ }^{14}$

Nyní je konečně možné upozornit na bod, který bude pro Husserla klíčový. Jak časová posloupnost, tak časové trvání jsou u Brentana uvědomované v tom kterém okamžiku pouze na př́islušné svislé linii diagramu, v níž jsou všechny prvky objektivní posloupnosti či objektivního trvání současně představovány. Současně s nimi jsou př́itomny i ty psychické fenomény (či Husserlovou terminologií - akty), v nichž jsou obsahy dány nenázorně. Jinými slovy, akty právě aktuálního vnímání, původní asociace, sekundární paměti jsou pro Brentana reálnými akty a nic reálného nemůže podle Brentana existovat jinak než v aktuálním nyní objektivního času. Tato ontologická teze je propojena s tezí deskriptivněpsychologickou. Stejně tak, jako budoucí akt nemůže intendovat budoucnost, nemůže minulý akt podržovat minulost. Akty, v nichž je objektivní čas vnímán, si musí být podle Brentana navzájem přitomné. ${ }^{15} \mathrm{~V}$ důsledku toho Brentano popírá časovou rozlehlost vnitřního vnímání. Aby se tato teze vyjasnila, je potřeba nejprve učinit několik poznámek k vnitřnímu vnímání. Každý psychický fenomén je ve svém intencionálním zaměření na primární př̀edmět (vidění na barvy, slyšení na tóny apod.) zaměřen mimochodem na sebe sama jakožto na předmět sekundární. ${ }^{16}$ Když vidíme barvy, jsme si mimochodem vědomi, že vidíme. Jelikož vnímání a vnímané je zde identické, je vnitřní vnímání evidentní, byt’ nemusí být jasné a artikulované. Přívlastek „mimochodem“ znamená, že předmět vnitřního vnímání, tj. psychický fenomén, který se vnímá, nemůže být nikdy předmětem pozornostního zaměření, nemůže být pozorován. Pozorování je možné až na základě pamět'ové

\footnotetext{
${ }^{13}$ James (1890, s. 646-647).

${ }^{14}$ Viz vylíčení obou těchto aspektů Brentanovy teorie u Husserla (1996, §§ 4-5).

${ }^{15}$ Brentanův prezentismus časového vědomí hájí i Meinong (1899) a Ehrenfels (1890), jejichž koncepce Husserl velmi dobře znal.

${ }^{16}$ Brentano (1874, s. 36, 187).
} 
rekolekce, která se na psychické fenomény zaměřuje jako na primární předměty. ${ }^{17}$ Př̀ výkladu časovosti vědomí ale musíme jít ve výkladu dále.

Vnitřní vnímání podle Brentana v posledku nazírá celek vědomí v intencionální artikulaci na své jednotlivé intencionální předměty, díky čemuž nejsou obsahy mysli disparátní, nýbrž uvědomujeme si je v reálné jednotě vědomí. ${ }^{18}$ Když vidíme a zároveň slyšíme, nejsou tu dva nespojené akty vnitřního vnímání, ale dán je jednotný fenomén, zaměřený na vidění a slyšení. ${ }^{19}$ Díky tomu víme, že současně vidíme $a$ slyšíme. Toto nazírání se vyznačuje evidencí a existence tohoto celku je zaručena. Stejně se to má i s celkem právě prožívaného vědomí. Vnitřní vnímání odhaluje v rámci jednoty reálného vědomí současnost aktů, které tuto jednotu vědomí utvářejí. Vědomí následnosti a trvání intencionálních předmětů v plynutí času je u Brentana založeno v jednom časově neextenzivním ohnisku.

Tato teorie, zdá se mi, má problém v následující oblasti. Jelikož vše, co je reálné, je podle Brentana časové, nemůže nic, co je reálné, existovat jen po dobu jednoho časového bodu, byt' reálně může existovat jen $v$ jednom časovém bodě, totiž $\mathrm{v}$ aktuálním nyní. Představa reálného předmětu, který zaniká v témže bodě, v kterém vzniká, je podle Brentana pojmově rozporná a nutnost minimálního trvání všeho reálného je pro Brentana samotného jasně formulovaným apriorním zákonem. ${ }^{20}$ Dokonce i Bůh je jakožto reálná entita u Brentana podroben trvání. ${ }^{21}$ Tuto ontologickou tezi doplňuje teze deskriptivněpsychologická. Máme totiž také jisté povědomí o tom, že i naše vědomí trvá, že má svou vlastní minulost. Když slyšíme melodii, nejsme si vědomi jen toho, že slyšená melodie nějakou dobu trvá, ale nějak víme, že trvá i její slyšení. Dokonce bychom mohli říci, že slyšení trvání (tónu či melodie) předpokládá trvání slyšení. Je zjevné, že zde se nám ukazuje první vážný problém, totiž jak jsme si vědomi trvání vědomí. Brentano, nakolik mohu říci na základě studia dostupných pramenů a sekundární literatury, jasné řešení tohoto problému nepodal. Několik propojených vodítek, z nichž některé budou zajímavé i pro Husserla, lze však vysledovat. Pokusím se je prezentovat v jejich problematičnosti.

Můžeme začít tím, že není náhoda, že Stumpf i Husserl ${ }^{22}$ takřka automaticky přejali pojem proudu vědomí (Bewußtseinstrom) od Williama Jamese, jenž ve svém díle

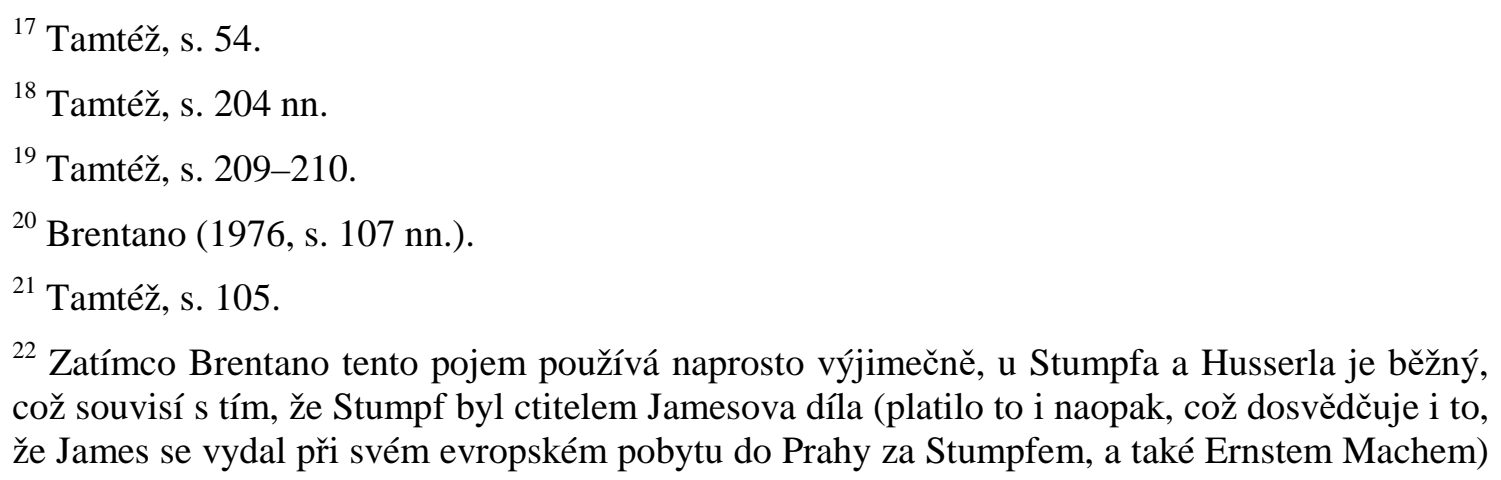
což souvisí s tím, že Stumpf byl ctitelem Jamesova díla (platilo to i naopak, což dosvědčuje i to, že James se vydal při svém evropském pobytu do Prahy za Stumpfem, a také Ernstem Machem) 
zpopularizoval anglický termín stream of consciousness. ${ }^{23}$ Ve skutečnosti se v Jamesovi domnívali nacházet jen to, co se v Brentanových textech domníval nacházet sám James, totiž plynutí celku vědomí, jehož jsme si vědomi. ${ }^{24}$

„Přechod mezi myšlenkou jednoho předmětu a myšlenkou druhého není přerušením myšlenky o nic více, než je koleno bambusu přerušením jeho dřeva ... Do vědomí hromu samého se vkrádá uvědomělé ponětí předchozího ticha a přetrvává v něm, nebot’ to, co slyšíme, když udeří hrom, není čistě hrom, ale hrom-vpadající-do-ticha-a-kontrastující-s-ním. Srov. Brentano, Psychologie, vol. I., s. 219-220. Tato Brentanova kapitola týkající se jednoty vědomí celkově vzato překonává všechno, s čím jsem obeznámen.“ 25

Ale jak si toto plynutí vědomí uvědomujeme? Podíváme-li se na Brentanovu Psychologii, nalezneme následující výroky. Základem je potvrzení teze, kterou jsme již vyhlásili.

„Jednota vědomí, jak ji evidentně poznáváme z toho, co vnitřně vnímáme, spočívá v tom, že všechny psychické fenomény, které se v nás současně nalézají jako nap̌r. vidění, slyšení, představování, souzení a usuzování, milování a nenávidění, toužení a odvracení se patří společně, bez ohledu na vzájemné rozdíly, $\mathrm{k}$ jednotné realitě, pouze nakolik jsou vnitřně vnímány jako existující společně ....“26

Povědomím o minulosti aktů se Brentano částečně zabývá ve složité tezi o podstatné neevidenci paměti.

„K jednotě vnímání konečně také nepatř̌́, že psychické fenomény, které obvykle označujeme jako dřivější duševní činnosti, byly částmi téže skutečné věci, která zahrnuje naše současné psychické jevy. Jedna věc je mimo veškerou pochybnost. Tak jako nám vnitřní vnímání prrímo ukazuje jen jistou reálně jednotnou skupinu psychických fenoménů, ukazuje nám pamět' vzhledem ke každému okamžiku minulosti přímo jen jednu takovou skupinu. O ostatních současných fenoménech nás zpravuje nepř́ímo tím, že

a že na jeho doporučení se podrobnému studiu Jamesových Principů psychologie věnoval i Husserl, viz Schuhmann (1977, s. 41).

${ }^{23}$ James (1890, s. 224-290).

${ }^{24}$ Nemůžeme zde hodnotit, nakolik bylo toto porozumění adekvátní. Srovnání pojetí frázování plynoucího kontinua vědomí u Jamese, Stumpfa a mladého Husserla by si vyžadovalo vlastní studii.

${ }^{25}$ James (1890, s. 240).

${ }^{26}$ Brentano (1874, s. 214). 
nám ukazuje, jak o nich existovalo poznání v rámci skupiny, o niž nám jde, podobně jako $\mathrm{v}$ rámci skupiny, kterou nám ukazuje vnitřní vnímání, může být obsažena víra v existenci jiných skupin.“27

Podle Brentana nám vnitřní vnímání nezaručuje existenci minulosti vědomí, nýbrž existenci reálných aktů paměti minulosti. Tyto akty jsou dány současně s dalšími akty $\mathrm{v}$ aktuálním celku vědomí. Pamětová rekolekce nám případně vybavuje minulé kontinuum stavů vědomí tak, že v každém zvoleném bodě se nám ukazuje celek psychických fenoménů, které v tomto bodě byly současné. Další v minulosti současné psychické fenomény, např. prožitky jiných osob či ta část naší psychické minulosti, která je zapomenuta (všichni věříme, že jsme prožívali více, než si pamatujeme), se dávají jen nepřímo.

To však není vše, pamět' je pro Brentana podstatně druhem instinktivní víry (Glaube, belief). Nemůžeme jinak než věřit, že vědomí má svou minulost. Jen tak je možné povědomí o trvání vědomí. Tato minulost je však předmětem paměti, nikoliv předmětem vnitřního vnímání, a je podstatně neevidentní. Že naše stavy byly takové, jak si je pamatujeme, věříme, ale nevíme to s evidencí. Není dokonce ani evidentní, zda vůbec nějaká minulost reálně proběhla. Podle Brentana bychom mohli být stvořeni naráz včetně obsahů paměti, a pak bychom věřili $\mathrm{v}$ minulost, která vůbec nebyla podobně jako některé filmy a seriály pracují s fikcí robotů, kteří se po výrobě probouzejí s naprogramovanou minulostí. Právě tak tvrzení, že minulost nevznikla „nyní“ je pro Brentana metafyzickou tezí podobně jako tvrzení, že existuje externí, transcendentní svět, který není závislý na existenci vědomí. ${ }^{28}$ Tato víra v minulost však není jen vždy instinktivně aktuálně prožívaná jako součást vědomého nyní, ale je také sama zahrnuta v obsahu paměti. Pamět' nám ukazuje minulou skupinu fenoménů, včetně víry v minulost, která byla v tehdejší minulosti přítomná. Jestliže si vzpomenu na slib, který jsem dal, je součástí rekolekce slibu i tehdejší víra v předcházející hodnocení, které jsem provedl a v němž se slib ukázal být preferovanou možností. Podle Brentana tato víra nemusí vést $\mathrm{k}$ rekolekci, kdyby totiž takovou rekolekci nutně vyvolávala, muselo by vybavení jednoho minulého momentu doprovázet postupné vybavení všech navázaných předcházejících psychických fenoménů - vybavení preference by vedlo $\mathrm{k}$ vybavení psychických fenoménů, které tuto preferenci předcházely, ty zase obsahují minulou víru v to, co předcházelo, jež by muselo být vybaveno atd.

Právě vyloženou pasáž Brentano doplňuje následně:

„Pamět' nám tak prrímo ukazuje jen jednu časově probíhající řadu skupin, z nichž každá byla reálnou jednotou, a tato řada tvoří kontinuum, které je tu a

\footnotetext{
${ }^{27}$ Tamtéž, s. 219.

${ }^{28}$ Brentano (1976, s. 92-93).
} 
tam narušeno mezerou. Při delším rozvažování se nám příležitostně daří tuto mezeru zaplnit ... závěrečný člen řady vytváří skupinu, kterou bezprostř̌edně pojímáme ve vnitřním vnímání. Toto zřetězení psychických jevů obvykle označujeme jako náš dřivější život a tak, jako říkáme: ,vidím‘, ,slyším‘, ,chci‘, když nám vnitřní vnímání ukazuje vidění, slyšení, chtění, říkáme, když nám pamět' ukazuje vidění, slyšení, chtění: ,viděl jsem‘, ,slyšel jsem‘, ,chtěl jsem‘، ‘29

Celé právě popsané pojetí povědomí o trvání vědomí je problematické. Není například jasné, jak můžeme vynášet výroky o právě aktuálním prožívání, které nemůžeme bezprostředně pozorovat. Než se ale jistým aspekti̊m této problematičnosti budeme věnovat, zkusíme představit některé zajímavé argumenty, které Brentano postupně vypracoval proti možnosti vnitřní proteresteze psychických fenoménů (tj. proti časové extenzi vnitřního vnímání).

Zaprvé musíme říci, že Brentano vůbec neuvažuje o tom, že by časovost vnitřního vědomí, kdyby se ji podařilo prokázat, mohla být konstituována $\mathrm{v}$ nějaké další sadě aktů, nebot' bychom si tím řekli o nekonečný regres. Okamžitě by vznikla otázka, jak si uvědomujeme časovost této nové sady aktů a zdali toto uvědomění existuje $\mathrm{v}$ jednom bodě, nebo má nějakou svou časovou rozlehlost. Termín „vnitřní vnímání“ byl Brentanem koneckonců postulován kvůli řešení takovýchto regresů. Stejně tak jako není psychický fenomén vnitřně vnímán dalším aktem, nemůže tak být vnímána ani jeho časová extenze.

Zadruhé je třeba uvést argument z názornosti vnitřního vnímání. Názor se u Brentana vyznačuje přítomností nazíraného. Proteresteze $\mathrm{v}$ tomto smyslu prezentuje časovou následnost či trvání předmětů. Jestliže vnímáme melodii, je nám její krátký úsek názorně přítomný. $\mathrm{K}$ čemu by došlo, kdyby se kromě přítomné následnosti tónů zpřítomňovaly i psychické akty slyšení? Podle Brentana bych kromě toho, že pojímám sebe sama jako $\mathrm{v}$ přítomnosti slyšícího právě minulý tón, navíc pojímal sebe sama jako někoho, kdo v minulosti slyšel přítomný tón. Jestliže je akt intencionální, je s jeho zpřítomněním zpřítomněn i jeho předmět, který byl tomuto minulému aktu dán jako přitomný. Brentano na tomto důsledku opakovaně trvá a ukazuje, že je v rozporu s naší zkušeností smyslového vnímání.

„Když něco pocit’uji jako minulé, nejedná se o vnitřní vnímání. I tehdy, když pocit’uji tón jakožto minulý, pocit’uji právě minulý tón, nikoliv minulé slyšení. ‘30

\footnotetext{
${ }^{29}$ Brentano (1874, s. 219).

${ }^{30}$ Brentano (1976, s. 88).
} 
„V tomto případě [primární] paměti se nejevím sám sobě jako někdo, kdo dřive pocit’oval něco jako přítomné, nýbrž jako někdo, kdo nyní pocit’uje něco jako minulé.“31

„Když slyším melodii, jeví se mi následnost tónů, nikoliv následnost slyšení. Neapercipuji sebe sama jako někoho, kdo něco právě slyšel, nýbrž jako někoho, kdo slyší jednu notu jako přítomnou a jinou notu jako minulou a ustupující stále do minulosti.“32

Kromě toho, že zkušenost smyslového názoru nesvědčí pro vnitřní časový názor minulých intencionálních aktů vnímání v průběhu vnímání, je také absurdní tvrdit, že jeden a tentýž tón slyšíme současně jako přítomně minulý a minule přítomný. To neznamená, že si podle Brentana nemohu vybavit minulý akt slyšení s př́slušnou modifikací časovosti vnímaného, jedná se však zjevně o následné vybavení neevidentního obsahu paměti a nikoliv o původní danost paměti zakládající vědomí o sukcesi psychických fenoménů $\mathrm{v}$ čase.

Další argumenty lze nalézt $\mathrm{v}$ jednom z pozdních Brentanových textů, který je přímo nadepsán „Reálné = časově kontinuální, vnitřní proteresteze neexistuje “. ${ }^{33}$ Brentano opakuje nejprve svou otázku.

„S vnějším vnímáním máme také vnitřní vnímání. ,Vidění‘, říká v tomto ohledu již Aristoteles, je ,mimochodem zaměřeno i na sebe samotné‘. A tak sebe sama vnímáme s evidencí jako představující si něco jako přítomné, právě tak i něco jako právě minulé a něco jako delší dobu minulé. Jeví se nám také sekundární předmět, poté, co se jevil jako přítomný, také jako minulý? ‘34

Brentano se domnívá, že tomu tak není. Kromě již výše vylíčeného argumentu uvádí ještě další.

„Jelikož vnitřní vnímání, které se nám nyní jeví jako minulé, bylo zaměřeno na vnitřní vnímání jakožto právě minulé, musí nám být i toto vnitřní vnímání nyní nepřímo dáno, a to se stejným časovým modem, s kterým se nám předtím jevilo. A jestliže tomu tak je, pak nám je nepřímo dán i dvakrát její primární předmět s časovým modem vědomí. Takto bychom museli pokračovat dále $\mathrm{a}$, jelikož by nám $\mathrm{v}$ proterestezi byla dána řada kontinuálně následujících vjemů (a tedy nikoliv jen jedna řada jako ve vnitřním vnímání

\footnotetext{
${ }^{31}$ Tamtéž, s. 86.

${ }^{32}$ Citát z Brentanova dopisu Stumpfovi uvedený Chisholmem (1981a, s. 14).

${ }^{33}$ Brentano (1976, s. 105-113).

${ }^{34}$ Tamtéž, s. 108-109.
} 
zaměřeném na současné psychické akty a zahrnující je), tato komplikace by vedla $\mathrm{k}$ nekonečné a nekonečněkrát nekonečné komplikaci, ba dokonce $\mathrm{k}$ nekonečné komplikaci na nekonečnou mocninu, což bychom mohli sotva připustit jako možné. ‘35

Tento argument je variací na předcházející. Jestliže má vnitřní vnímání časovou extenzi, není s evidencí zaměřeno pouze na právě současné vnitřně vnímané akty, nýbrž i na minulé vnitřně vnímané akty (na minulé vnitřní vnímání). V zaměření na minulé vnitřní vnímání se tedy jedná o zaměření na kontinuální řadu minulých vnitřních vjemů (řada 1), ${ }^{36}$ které se postupně propadají do minulosti a které uzavírá vnitřní vjem, jenž je právě přítomný. Bezprostředně minulý vnitřní vjem by se nám pak ale ukazoval jako vjem, který byl přítomný a který byl $\mathrm{v}$ této minulé přítomnosti zaměřen na tenkrát právě minulou řadu vnitřních vjemů, kterou tenkrát jakožto přítomný uzavíral (řada 2). Zvolený libovolný bod této minulé řady 2 by se ale opět jevil jako v minulosti př́itomný v zaměření na kontinuální řadu tehdejší minulosti vnitřního vnímání, kterou jako prrítomný uzavíral (řada 3). V řadě 2 a 3 je nekonečno možných bodů, které samy zahrnují nekonečna dalších bodů, z nichž každý opět zahrnuje nekonečno, a tak dále do nekonečna. Již bezprostředně minulý bod řady 1 vede $\mathrm{k}$ takovéto komplikaci, řadu 1 ale opět tvoří potencionální nekonečno dalších bodů, z nichž každý vyvolává tuto komplikaci. Brentano se následně snaží vyřadit i možné protiargumenty, které by se snažily nekonečně nekonečný regres blokovat. Jimi se zde zabývat již nemůžeme.

Uvidíme, že Husserl se s tímto Brentanovým argumentem seznámil kolem roku 1908, že jej velmi dobře pochopil a že pro něj představoval poslední hřebík do rakve teze, že vědomí vnitřního vědomí času má v posledku časovou extenzi.

Vrat'me se nyní na závěr $\mathrm{k}$ avizované problematičnosti Brentanova vnitřního „prezentismu“. Současná existence všech aktů vědomí, v nichž se konstituuje časovost fenomenálních předmětů, je existencí v jednom bodě času. Jakého času? Zjevně času objektivního. Stejně jako za sebou následují na vodorovné ose Brentanova časového diagramu tóny, následují za sebou vodorovně i svislé narůstající sukcesivní skupiny proteresteze tónů. Tyto svislé skupiny - byt’ se z nich stávají možné obsahy následného pamět'ového vybavení - navzájem př́icně či spíše úhloprříčně nespojuje žádný názor. Názorné propojení by vyvolalo výše popsané problémy. Vše, co existuje jako přítomné, je ale reálné, a podle Brentana vše, co je reálné, objektivně trvá v čase. Otázku, jak vědomí objektivně trvá v čase, musíme nyní zcela odlišit od otázky, kterou jsme se zabývali zejména, totiž jak si můžeme být tohoto trvání vědomí vědomi. V Brentanově ontologii časového kontinua je bod aktuální přítomnosti vyložen jako nesamostatná

${ }^{35}$ Tamtéž, s. 109-110.

${ }^{36} \mathrm{~V}$ této řadě je podle Brentana obsaženo potencionální nekonečno hranic, v nichž ho lze dělit. Brentano tyto nesamostatné hranice považuje za body kontinua. 
hranice, která si žádá doplnění dimenzí minulosti a budoucnosti. Bytí prrítomného nyní je však pro Brentana reálným bytím. Brentano uznává „hranici“ jako kategorii reálného jsoucna. V té Brentanově teorii, kterou znal Husserl, minulost a budoucnost existuje ireálně. V trvání vědomí by tedy byla kontinuálně spojena reálná hranice př́ítomnosti s dimenzemi ireálnými. Jakékoliv kontinuální spojení reálného s ireálným je ale paradoxní. ${ }^{37} \mathrm{~V}$ Brentanově ontologii je tento problém jedním $\mathrm{z}$ motivů pro přechod $\mathrm{k}$ reismu, tj. k extrémní metafyzice, která tvrdí, že jiné než reálné předměty neexistují a že nic než (existující či neexistující) reálný předmět si ani nejsme schopni představit. ${ }^{38}$ Jestliže však v reismu není minulost a budoucnost reálná, pak není. Hranice přítomnosti tak nemá nic, co by spojovala, a nemůže tedy být hranicí. Pokud bychom nyní tvrdili, že čas se vědomí ukazuje pouze v rámci současných reálných aktů vědomí a že v reálných aktech paměti a očekávání se konstituuje i vědomí o empirickém trvání vědomí, vedlo by to $\mathrm{k}$ tvrzení, že přítomnost těchto aktů vůbec není v čase. Pak ovšem nemůže být podle Brentanovy vlastní teze toto vědomí reálné. Brentano by takový výsledek považoval za vrcholně neuspokojivý.

Druhý problém je deskriptivněpsychologický. Jestliže jsou minulé psychické fenomény předměty paměti a nikoliv předměty vnitřního vnímání, není vůbec zřejmé, jak by nám mohla reflexe ukazovat kontinuální řadu psychických fenoménů zakončených v právě vnitřně prožívaném celku vědomí. Intencionální prožitek, který je ve svém vnitřním vnímání pro sebe předmětem, má být podle této nauky vzápětí modifikován v předmět paměti a časově odsunut. Brentano jednak nevysvětluje, o jaký typ paměti se zde jedná a jak přesně se o něj opírá vzpomínka, jednak tato modifikace nemůže být kontinuální změnou. Psychický fenomén může být bud' vnitřně prožíván, nebo dán jako předmět jiných aktů. Nemůže se ale nacházet někde mezi - v kontinuálním přechodu z jednoho stavu v druhý. Jinými slovy, Brentanovi se nepodařilo srozumitelně popsat vědomí kontinuity vědomí, které se zdá být přece zkušenostně vykazatelné.

\section{Husserlova kritika Brentanova prezentismu}

Husserl přistupuje k teorii vnitřního časového vědomí z hlediska teorie intencionality, která se od Brentanovy nauky výrazně liší. Již v Psychologische Studien zur

\footnotetext{
${ }^{37}$ Viz Brentanův argument v Krausově textu, Kraus (1930, s. 7). Pro Brentana i pro Husserla to $\mathrm{v}$ deskriptivní psychologii znamená posun $\mathrm{k}$ teorii, která časovou modifikaci předmětù vědomí nahrazuje modifikací aktů, v nichž je časově představován jeden a tentýž předmět. Padla totiž původní teze, že vnímání časové extenze tvoří představené kontinuum momentů, z nichž jeden je reálný a zbylé ireálné.

${ }^{38}$ Detailnější popis reismu nabízí Chisholm (1981b). Základní texty Brentanova reismu jsou obsaženy v Brentano (1977).
} 
Elementaren $\operatorname{Logik}^{39}$ zavedl Husserl dva základní navzájem neredukovatelné intencionální charaktery představování, a sice reprezentace a názory.

„Jisté psychické prožitky jsou specifické tím, že v sobě své předměty neobsahují jako imanentní (tj. jako přítomné ve vědomí), nýbrž pouze je intendují způsobem, který bude potřeba ještě přesněji učit. “40

Prožitky pouhé intence, čili reprezentace, jsou takř́kajíc prázdné. Mají sice podle mladého Husserla svůj názorný imanentní obsah, ale ten slouží pouze jako poukaz na něco dalšího, nenazíraného. Oproti tomu názory mají svůj imanentní obsah v sobě, nejsou to tedy pouhé intence. Tyto typy psychických fenoménů se mohou vzhledem $\mathrm{k}$ jednomu a témuž imanentnímu obsahu křižit. Strana židle, kterou právě vidím, je imanentním obsahem názoru, zároveň se o ni ale „opírá“ prázdná intencionalita, která míní skryté strany židle.

Husserlovi toto rozlišení umožňuje nově definovat názor v širším smyslu jako prožitek vyplnění prázdné intence intencí názornou. Stránku židle, kterou jsem pouze mínil, mohu mít dánu následně názorně s vědomím vyplnění předchozí pouhé intence. Je pozoruhodné, že Husserl v tomto raném textu již vztahuje názory k fenomenálním předmětům a $\mathrm{k}$ aspektům těchto předmětů - $\mathrm{k}$ právě viděné perspektivě domu či právě slyšené části melodie. ${ }^{41}$ Hovoří-li o imanentním obsahu, nemyslí tu tedy na Brentanovy fyzické fenomény či na smyslová data. Díky tomu hraje v tomto textu základní roli vztah intence k budoucnosti. Domy a melodie můžeme nazírat jen v širším smyslu, tj. v postupném vyplňování jejich prázdně předjímaných stránek. Podle raného Husserla nemůže být dům či melodie imanentní žádnému právě př́itomnému aktu, nýbrž pouze celému průběhu postupně vyplněné intence. ${ }^{42}$ Intence vnímání fenomenálního předmětu je podle raného Husserla završena, jestliže jsme s věcí hotovi - melodie dozněla, na viděném předmětu již není nic dalšího zajímavého k nahlédnutí. Jelikož tato intence, která se postupně završuje, trvá, musí se trvání vědomí konstituovat ve vnitřní časovosti vědomí samého. Vědomí trvání této vyplňující se intence je pro Husserla podmínkou jednoty názoru fenomenálního předmětu (jednoty časového „odstiňování“).

V roce 1894 se Husserl seznámil se spisem Kazimíra Twardowského Zur Lehre vom Inhalt und Gegenstand der Vorstellungen ${ }^{43}$ a pod jeho vlivem opět proměnil svou teorii představování. Podle Twardowského je $\mathrm{v}$ Brentanově teorii jistá ambivalence $\mathrm{v}$ tom, jak hovoří o intencionálním obsahu. Stejně jako se krajinou zobrazenou na plátně

\footnotetext{
${ }^{39}$ Husserl (1894).

${ }^{40}$ Tamtéž, s. 175.

${ }^{41}$ Viz popis těchto předmětů jako předmětů názoru v běžném smyslu v Husserl (1894, s. 178).

${ }^{42}$ Husserl (1894, s. 178).

${ }^{43}$ Twardowski (1894).
} 
může myslet bud' obraz na plátně, anebo skutečná krajina, kterou někdo učinil tématem obrazu, lze intencionálním obsahem mínit bud' obsah, díky němuž jsme zaměřeni na ten či onen intencionální předmět, anebo tento předmět sám. ${ }^{44}$ Pro nás je důležité, že Husserl si toto opatření upravil pro své potřeby. Pod vlivem Bolzana odlišil logicky objektivní obsah představy od subjektivního obsahu, který je $\mathrm{v}$ pravém smyslu imanentně obsažen v představě jakožto její imanentní „význam“. Tentýž objektivní obsah může být obsahem mnoha subjektivních aktů. ${ }^{45}$ Vztah mezi těmito typy obsahů Husserl později určil platónsky pomocí instanciace obecného v konkrétním. Měli bychom si všimnout, že každá intence nyní musí mít podle Husserla významový obsah, který ji takříkajíc zaměřuje na její intencionální předmět. Reprezentace a názory jsou nyní dvě formy intencionálního zaměření na předmět. To má drastický dopad na teorii smyslového vnímání. Psychické fenomény pocit’ování nemohou mít fyzické fenomény za své předměty tak, jak je tomu u Brentana. Podle raného Husserla totiž nemá smysl říkat, že např. prosté pocit’ování červeně má nějaký (bolzanovský) významový obsah, který by ho zaměřoval na počitek červeně ve smyslu fyzického fenoménu. Nemá také smysl říkat, že dvoje pocit’ování červeně intenduje díky nějakému svému smyslu numericky tentýž počitek. Z Brentanových imanentních obsahů smyslové percepce, které ale nejsou ve fenoménech obsaženy reálně, nýbrž právě intencionálně, se u Husserla stávají imanentní neintencionální obsahy ve smyslu „slepých“ prožitků. Podle raného Husserla jsou $\mathrm{v}$ reálném vědomí obsaženy reálně, později hovoří Husserl neutrálně o jejich „reelním“ obsažení. Intencionální prožitky se nyní vyznačují smyslem, který formě intence předepisuje, jak je třeba počitky interpretovat, jak se mají pojímat.

Mění se i pojetí vyplnění intence. Prázdná a názorná intence mohou mít stejný smysl a vyplnění prvé druhou je nyní Husserlem popsáno v Logických zkoumáních jako vyplnění smyslu. ${ }^{46}$ Předjímáme-li v pojetí neviděnou stránku židle, je tento parciální akt vyplněn ve svém smyslu smyslem názorné intence, jestliže se dotyčná stránka židle skutečně ukáže. Počitky jsou interpretací takříkajíc objektivovány, vztaženy jako aspekty $\mathrm{k}$ fenomenálnímu předmětu, který se $\mathrm{v}$ těchto aspektech jeví, který na ně ale není redukovatelný. Husserl tím ustanovil dvojici imanentní počitkový obsah a jeho pojetí (osmyslnění) jako nezbytný prvek výkladu jakéhokoliv vnímání, včetně vnímání časovosti předmětů zkušenosti.

\footnotetext{
44 Tamtéž, s. 3-5.

${ }^{45}$ Následující shrnutí Husserla je obsaženo v Husserlově recenzi spisu Twardowského, Husserl (1979, s. 349-356).

${ }^{46}$ Husserl o vyplnění smyslu nejprve hovoří v analýze vyjadřovacích aktů, ale přenáší toto pojetí i na všechny objektivující akty, včetně aktů smyslového vnímání. Viz Hussel (1901, s. 50-52, 386-391).
} 


\section{Husserlovo původní východisko v přednáškách $k$ vnitřnímu časovému vědomí.}

Změny, kterých se dočkalo Husserlovo pojetí představování, ${ }^{47}$ znamenají, že Husserlova pozice je vůči Brentanově mimoběžná. Tato mimoběžnost se dále stupňuje Husserlovým metodickým rozhodnutím nevyužívat při analýze času žádné transcendentní předpoklady a analyzovat pouze jevící se čas.

„Vzhledem k časovému problému to znamená toto: časové zážitky nás zajímají. Že ony samy jsou určeny objektivně časově, že patří do světa věcí a psychických subjektů a že v nich mají místo, o tom nic nevíme.““8

V časových zážitcích jsou míněna objektivní časová data, tj. objektivní trvání a vztahy následnosti zkušenostních předmětů (fenomenálních předmětů ve smyslu melodií, domů, židlí, věcných vlastností fenomenálních předmětů atd.). Husserl před obratem $\mathrm{k}$ noematické fenomenologii má v přednáškách za to, že pravá fenomenologická analýza nesmí překračovat to, co je zaručeně dané, tj. danost prožitků, v našem případě danost časových jednot prožitků. Tím je za předmět zvolena analýza imanentních obsahů vědomí či spíše analýza časových jednot těchto obsahů. Prožitky, v nichž je míněn (konstituován) objektivně se jevící čas predmětů, jsou dvojího typu, a sice neintencionální imanentní smyslová data a intencionální akty čili formy pojetí, které datům udílejí smysl. ${ }^{49}$ Husserl nyní zaměřuje pozornost na tuto oblast a tvrdí, že čas uvědomovaný na této rovině, není (bez dalšího) objektivním časem.

„,.. bez dalšího není např. ,zároveň‘, jež je pocit’ováno, objektivní současností ... pocit'ované absolutní časové datum není bez dalšího prožitím objektivního času (to platí i pro absolutní datum onoho Ted').“50

${ }^{47}$ Husserl v Logických zkoumáních oficiálně opustil základní Brentanovu tezi, podle níž je představování samostatným psychickým fenoménem. Podle Husserla je představování nesamostatným momentem objektivujících aktů, v nichž je to, co je představeno, kvalifikováno vírou a jejími modifikacemi (problematičností, supozicí, otázkou, zdržením se víry apod.). Viz Husserl (1901, s. 386-391).

${ }^{48}$ Husserl (1996, s. 17).

${ }^{49}$ Husserlovo vydání přednášek je v jistém smyslu nečitelné, protože Husserl v nich používá termín „imanentní obsah“ v následujících významech - 1. pojetí včetně pojatého smyslového data (v tomto smyslu hovoří také o jevu - Erscheinung, nebot' pojatý obsah je odstíněním objektivní časovosti fenomenálního předmětu), 2. pojetí bez pojatého obsahu (v př́ípadech 1 a 2 užívá také bez rozlišení termín Auffasung), 3. nepojaté smyslové datum. Když hovoří o konstituci imanentního obsahu, nelze často rozhodnout, o který význam termínu se opírá, což zabraňuje porozumět detailům Husserlových deskripcí.

${ }^{50}$ Husserl (1996, s. 15). Brentano by tuto tezi určitě považoval za pomýlenou, nebot' se rovná tvrzení, že prožitek není bez dalšího reálným prožitkem. Jelikož podle Brentana nám vnitřní vnímání odhaluje nejen existenci, ale také realitu prožitků, znamenalo by to popř́ít evidenci předmětu vnitřního vjemu. Husserl má naopak tuto evidenci za evidenci psycho-fyzické apercepce subjektu, která musí být sama podrobena redukci. 
Objektivním časem tu myslí Husserl právě čas transcendentní, který byl vyřazen v rámci metodologického východiska přednášek. Brentanova perspektiva je jiná. Brentano pečlivě odlišuje prožitek objektivního času (vědomí trvání) od objektivního času prožitku (trvání vědomí). Jedno se nesmí zaměňovat s druhým. Jestliže je ale prožitek času reálným prožitkem, musí být sám $\mathrm{v}$ objektivním, reálném čase a musí v něm mít sám nějaké reálné trvání. Jestliže je aktuální, musí být aktuální v bodě přítomnosti reálného času. Prožívání času je pak „konstituováno“ jen v realitě právě aktuálního vědomí a trvání vědomí (jeho minulost) se na této konstituci nepodílí. Husserlovo přepracované pojetí názoru si však vyžaduje, aby se prožitek trvání vědomí podílel na konstituci objektivního časového názoru. Byt' se $\mathrm{v}$ původních přednáškách nehovoří takřka vůbec o protenci, Husserl neustále říká, že napřr. znění tónu či melodie trvá, dokud se neuzavře. Tón či melodie se však uzavře, jestliže se vyplní intence, díky níž se znění jeví jako přítomné. Právě proto je možné, aby se tón po „uzavření“ jevil jako minulý, zatímco melodie, jejîž je částí, se stále jeví jako přítomná. To je podle Husserla možné jen díky tomu, že jsme si vědomi trvání této vyplňující se intence, tj. trvání pojetí smyslových dat, v němž se kontinuálně „realizuje“ přítomnost melodie, z níž je část minulá, část přítomná a část dosud nenaplněná. $Z$ jiného úhlu pohledu lze také réíci, že předměty jakožto objektivní jednoty se odstiňují v jednotách svých odstínění (v jednotách jevových průběhů). Jednoty jevů jsou samy vyloženy na základě časových jednot obsahů a jejich pojetí.

Původní Husserlova fascinace konstitutivní rolí vnitřního časového trvání pro ustanovení časového vědomí fenomenálních objektů a otázka, jak se samo toto trvání konstituuje, vedla Husserla ke značnému podcenění argumentů, které proti této roli vyslovil Brentano a jeho žáci. Jak původní přednášky, tak Husserlovy manuskripty, ${ }^{51}$ toto prvotní podcenění prozrazují. V přednáškách se Husserl s odvoláním na W. Sterna staví proti „,dogmatu o momentaneitě celku vědomi“, tvrdí, že „,vněm časového objektu má sám časovost, že vněm trvání sám předpokládá trvání vněmu, že vněm libovolné časové podoby má sám časovou podobu“. 52

Brentano však netvrdí, že prožitky nemají časovou rozlehlost (právě naopak nějakou rozlehlost jakožto reálné mít musí), ale že minulý prožitek nemůže konstituovat vnímání minulosti a budoucí prožitek nemůže konstituovat vnímání budoucnosti. Dále tvrdí, že při prožívání časovosti melodie se nám názorně nejeví akt slyšení tak, že by se jedna jeho část jevila jako př́ítomná a jiné části by se jevily jako ustupující do minulosti. Názor fenomenálních předmětů smyslů nemůže doprovázet názor aktů smyslového vnímání. Nemůžeme během vnímání podržet názorné vnímání fenomenálního objektu jako vodítko a zároveň se obrátit k názoru prožitků, nebot' tento obrat je modifikací

\footnotetext{
${ }^{51}$ Viz Husserl (1985).

${ }^{52}$ Husserl (1996, s. 27, 29).
} 
časovosti fenomenálních objektů. Přítomné slyšení minulého tónu by bylo současně minulým slyšením (tehdy) prŕtomného tónu. Dále Brentano tvrdí, že intencionalita, která se pojí s vědomím minulosti, je intencionalitou paměti a nikoliv intencionalitou vnitřního vnímání. Ve chvíli, kdyby se evidence vnitřního vnímání zaměřila na minulé evidentní vnímání, vznikl by nekonečně nekonečný regres.

Husserl oproti tomu vytýká Brentanovi, že pro vysvětlení jevu časovosti předmětů nevyužívá dvojici obsah - pojímající akt.

„Brentano nerozlišuje mezi aktem a obsahem, popř́ípadě mezi aktem, obsahem pojetí a pojatým předmětem ... Časové charaktery, sukcese a trvání nenacházíme pouze na primárních obsazích, nýbrž také na pojatých obsazích a pojímajících aktech. Časová analýza, která se omezuje na jednu vrstvu, není dostačující, musí spíše sledovat všechny vrstvy konstituce.“53

Husserlovi je třeba přiznat, že tato kritika je oprávněná, zároveň však sama obsahuje tak zjevný nekonečný regres, že je s podivem, jak ji mohl myslitel Husserlova formátu v této podobě vůbec vyslovit.

U Brentana se analýza časovosti týká fyzických fenoménů, tj. imanentních předmětů intencionálních fenoménů pocit’ování. Husserl si je dobře vědom, že v jeho schématu by se tedy týkala časovosti samotných smyslových dat. Brentano sice tvrdí, že vztahování těchto dat $\mathrm{k}$ fenomenálním předmětům je noetickým výkonem vyššího řádu, žádnou skutečnou analýzu jejich pojetí ale nepodává a zjevně si ji ani neuvědomuje jako desideratum. Husserl naopak v roce 1905 tvrdil, že veškerá konstituce předmětů vnímání má schéma obsah pojímání - pojímání. Jestliže se konstituuje vnitřní časovost smyslových dat a jejich pojetí, pak vznikne uplatněním tohoto schématu na vnitřní konstituci nekonečný regres, který doslova bije do očí. Vnitřní časovost by se konstituovala v pojetí a obsazích, které jsou samy časové a tudíž konstituované dalším pojetím obsahů atd. Navíc není vůbec jasné, co by mělo hrát roli pojímaného obsahu při konstituci časovosti smyslových dat a časovosti jejich pojetí a v jakém smyslu by mohl být počitek a pojetí počitku intencionálním předmětem této vnitřní konstituce. Intencionální předmět je u Husserla původně chápán jako transcendentní vůči své intenci a schéma obsah - pojetí je zavedeno, aby tuto transcendenci vysvětlilo. ${ }^{54}$ Brentano oproti tomu považoval modifikaci obsahů za primitivní, původní danost vědomého života. Když pochopil, že tuto modifikaci nemůže připsat obsahům, protože reálné obsahy by byly kontinuálně spojeny s ireálnými, vysvětlil ji jako pưvodní modifikaci ve způsobu představování fyzických fenoménů. Způsob představování téhož fenoménu se kontinuálně mění tak, že tento fenomén časově ustupuje do minulosti.

\footnotetext{
${ }^{53}$ Tamtéž, s. 24.

${ }^{54}$ Podobným problémem, zdá se, trpí i Husserlovo pojetí reflexe.
} 
Naznačili jsme, že jak schéma obsah - pojetí, tak časová extenze, v níž se má odehrávat konstituce časových charakterů vyššího řádu vedou k nekonečnému regresu. Husserl, jak je zjevné z manuskripti̊ a z pozdějších vrstev publikovaných přednášek, si oba tyto problémy uvědomil. Můžeme předeslat, že pokud má Husserl pravdu a ke konstituci jednoty názoru (jednoty odstínění) časového předmětu je třeba vědomí o trvání této jednoty a pokud má sama tato jednota intencionální povahu, která předepisuje, co ještě platí jako kontinuální názor jednoho a téhož předmětu, pak je třeba připustit, že vědomí trvání vědomí hraje podstatnější roli, než se domníval Brentano. Zprvu se však zdá, že celá tato perspektiva by měla být nějak formulovaná z hlediska prezence. Kdybychom si nyní neuvědomovali trvání časového názoru, pak by se nyní nemohla konstituovat ani objektivní časovost fenomenálního předmětu, který je nazírán. Jindy než nyní si jednotu př́ítomnosti, minulosti a budoucnosti uvědomovat nelze. Kdyby věci zůstaly takto, Brentano by takř́kajíc zvítězil v druhém kole. Tak tomu však není. Mezi lety 1907-1911 zavádí Husserl do svého pojetí tezi o absolutním vědomí. ${ }^{55}$ Husserl tvrdí, že toto vědomí, v němž se konstituují veškeré obsahy časového proudu vědomí, je $\mathrm{v}$ jistém smyslu absolutním vědomím živé současnosti (lebendige Gegenwart) všech imanentních obsahů vědomí. Nakonec ale odmítne tezi, že by tato současnost existovala „naráz“ v hranici přítomnosti náležící k objektivnímu času. Místo toho má stát časový charakter absolutního vědomí mimo jakýkoliv objektivní čas, či spíše ,před“" ním.

Zamysleme se na závěr nad touto tezí. Jedním ze základních textů, v němž Husserl dospívá k odmítnutí bodové povahy absolutního vědomí, je rukopis vydaný jako č. 50 s názvem $O$ primární modifikaci paměti v rámci textů k fenomenologii vnitřního časového vědomí. ${ }^{56}$ 15. ř́ijna 1908 obdržel Husserl poštou knihu Martyho a Brentanova pražského žáka Hugo Bergmanna Untersuchungen zum Problem der Evidenz der inneren Wahrnemung, ${ }^{57}$ který na s. 82 obsahuje Brentanův argument nekonečně nekonečného regresu. Husserl si ho podrobně nastudoval a v textu č. 50 se jej pokouší řešit, přičemž si celý problém př̀kládá do vlastní terminologie. Jestliže má být vědomí o vědomí vědomím proudu vědomí čili jistého pohybu vědomí, pak je vědomím o jistém časovém rozpětí tohoto vědomí (rozpětí A). Každý bod toho rozpětí byl však ve chvíli, kdy byl aktuální, sám vědomím časového rozpětí (rozpětí B), každý bod rozpětí $\mathrm{B}$, byl ve chvíli, kdy byl aktuální, vědomím rozpětí $\mathrm{C}$ atd. do nekonečna. Vzpomínka na počáteční tón melodie $\mathrm{A}$ by při přítomném znění třetího tónu melodie $\mathrm{C}$ zahrnovala i všechny vzpomínky na vzpomínky A, každá z těchto vzpomínek by opět zahrnovala vzpomínky na vzpomínky A, které byly tehdy aktuální atd. To samé se týká

\footnotetext{
${ }^{55}$ Viz podrobnou analýzu Rudolfa Berneta, Bernet (1985, s. XXXIII-XLV).

${ }^{56}$ Husserl (1985, s. 190-200).

${ }^{57}$ Bergmann (1908).
} 
i vědomí druhého tónu $\mathrm{B}$ a vlastně vědomí všech minulých bodů ležících na rozpětí vědomí od přítomného $\mathrm{C} \mathrm{k}$ minulému $\mathrm{A} .^{58}$ Připomeňme, jak činí i Husserl, ${ }^{59}$ že všechna tato kontinua vědomí mají být současně uvědoměna $\mathrm{v}$ jednom jediném nyní, at' již pod tímto nyní rozumíme cokoliv.

Husserl má sice za to, že matematicky je taková teze formulovatelná, ale těžko ji přijmout jako popis vědomí. Deskriptivně je zjevně nepř́ípustná. Když jsme si vědomi časové jednoty, $\mathrm{v}$ níž se odstiňuje tón, jsme si (pre-reflexivně) vědomi pouze jediné kontinuální jednoty, která trvá jako tatáž, dokud trvá názor časového předmětu. Aby Husserl mohl celý problém zvládnout, musí učinit několik zásadních rozhodnutí. Zaprvé v závěru rukopisu č. 50 začne Husserl odlišovat primární vzpomínku (primární pamět') a retenci.

„Pamět' je výraz, který se vždy vztahuje ke konstituovanému časovému předmětu; retence je ale výraz, který lze využít k označení (zásadně jiného) intencionálního vztahu fází vědomí $\mathrm{k}$ fázím vědomí, přičemž fáze vědomí a kontinua vědomí nemohou být samy interpretovány jako časové předměty. “60

V pozdní vrstvě Přednášek toto rozlišení figuruje jako rozlišení dvojí retencionality.

„Každé odstínění vědomí druhu ,retence“ má dvojí intencionalitu: jednu tu, jež slouží pro konstituci imanentního objektu, tónu, to jest tu, kterou nazýváme ,primární vzpomínkou“ na (právě prožitý tón) nebo zřetelněji retencí tónu. Druhá je ta, jež je konstitutivní pro jednotu této primární vzpomínky toku, totiž retence je vjedno s tím, že je ještě-vědomím, zadržujícím, právě retencí, retencí uplynuvší retence toku. “61

Jinými slovy, časová jednota se konstituuje ve vzpomínce díky příčným retencím. Každá nová fáze znění melodie díky nim zdědí příslušný úsek předcházející primární vzpomínky, ten takřrikajíc „klesne“ do její svislé osy. Ta v následujícím okamžiku díky retenci celá klesne do následující svislé osy nové primární vzpomínky. Zachovává se však i minulost tohoto klesání (retence retencí). Názorná je však jen konstituovaná časová jednota jakožto korelát aktuálního vjemu a primární vzpomínky, a to navíc $\mathrm{v}$ slabém smyslu (její názornost lze učinit tématem reflexe), v pravém smyslu je názorný fenomenální předmět s objektivními časovými určeními. Husserl zároveň na úrovni absolutního vědomí opouští schéma obsah - pojetí a vrací se k terminologii, která je téměř k nerozeznání od Brentanovy. Retence je nyní originální syntézou časovosti

\footnotetext{
${ }^{58}$ Husserl (1985, s. 194-195).

${ }^{59}$ Tamtéž, s. 196.

${ }^{60}$ Tamtéž, s. 199.

${ }^{61}$ Tamtéž, s. 80.
} 
(původní asociací). Retencionální modifikace primární modifikace se děje „sama od sebe“ a nepotřebuje k tomu nějaké pojímání obsahů. Máme tedy vědomí o trvajícím rozvíjení aktuální časové jednoty (či obecně vzato máme vědomí o trvajícím proudu vědomí), které je podmínkou pro konstituci časové jednoty. Husserl však zdůrazňuje, že konstituce tohoto proudu už vlastně není konstitucí, nýbrž čirou spontaneitou čili samokonstitucí vědomí jakožto proudící jednoty v sobě samém.

„Proud vědomí je si sice sám následností, sám od sebe ale splňuje podmínky možnosti vědomí následnosti. “62

Brentanův argument zde však takříkajíc vrací úder.

„Otázka přece zní, jak mohu dospět k ,vnímání‘ proudu analogicky k vnímání tónového pohybu. Vnímám vůbec někdy proud [vědomí]? Nemohu fenomenologicky zaujmout takové stanovisko, z něhož jsem místo zaměření na tóny zaměřen na vědomí, na následnost tónových nyní spolu s jejich pamětovými ocasy? Zdá se tedy, že bychom kreslení [časového diagramu] museli přece jen opakovat do nekonečna. To je ale nemyslitelné. “63

Aby se Husserl vyhnul regresu, musí popřít, že by příčně retencionální vědomí bylo vnímáním v jakémkoliv běžném smyslu (během vnímání minulosti fenomenálního časového předmětu nedochází $\mathrm{k}$ vnímání minulosti aktů, v nichž se tato jednota ustanovuje). Vědomí o proudu vědomí (sebevědomí) je dále jakýmsi ur-vědomím, které samo není názorné. Absolutní vědomí samo sebe nekonstituuje jako časově rozlehlý proud, $v$ absolutním vědomí jsou všechny obsahy dány současně, tj. v nyní, ale toto nyní nemá žádnou minulost, vůči které by se mohlo kontrastovat jako př́ítomnost $\mathrm{v}$ normálním smyslu slova. Následnost není v rámci absolutního vědomí časovým průběhem. Nelze tedy říci, že by absolutní sebe-vědomí bylo vědomím nějakého objektu či časové jednoty $\mathrm{v}$ jakémkoliv běžném smyslu. Důvod tohoto tvrzení se vykládá v následujícím citátu:

„Není však absurdní pohlížet na časový proud jako na objektivní pohyb? Je! $\mathrm{Na}$ druhou stranu je přece vzpomínka něčím, co má samo své nyní a totéž nyní jak například tón. Ne. Tady máme základní chybu. Proud vědomí není žádným procesem, vědomí nyní (Jetzt-Bewußtsein) není samo nyní. ,Společné‘ bytí retence dané s vědomím nyní není ,nyní‘, není současné s nyní, něco takového naopak nedává smysl ... Počitek, jestliže jím rozumíme vědomí (a ne imanentní červeň, tón apod., tj. to, co pocit’ujeme), a právě tak retence, opětná vzpomínka, vnímání atd. jsou nečasové, nejsou ničím v imanentním čase (míra, $\mathrm{v}$ níž jsou objektivovatelné $\mathrm{v}$ př́rodě, $\mathrm{v}$

${ }^{62}$ Tamtéž, s. 198.

${ }^{63}$ Tamtéž, s. 199. 
,objektivním“ čase je samostatnou otázkou). Zde běží o nanejvýš důležité věci. Možná o nejdůležitější v celé fenomenologii). “64

Dogma o momentaneitě časového vědomí, v němž měl naivně žít Brentano, nakonec není pro Husserla takové dogma. Husserlovo absolutní vědomí je v tomto smyslu jakýmsi pohrobkem přítomnosti vědomí v bodě nyní. Husserl však svou tezi o absolutním vědomí psal již z hlediska svého trancendentálního idealismu. Konstituující vědomí nemůže být částí přírody, nemůže tedy být o sobě obsaženo v bodu přítomnosti objektivního času (může však samo sebe takř́kajíc objektivovat v rámci objektivní konstituce přírody). Jelikož veškerý jev následnosti a současnosti se konstituuje díky tomuto vědomí, nemohou se obsahy tohoto vědomí vyznačovat běžnou následností či současností, jsou v tomto smyslu „nečasové“ či lépe řečeno - nachází se v předčasové oblasti. Veškerá určení tohoto vědomí jsou vlastně jen metafory. Otázka, jak může být absolutní vědomí předmětem fenomenologické reflexe, jejíž jednota je přece imanentně časovou jednotou, vede rovnou $\mathrm{k}$ pochybnosti, nakolik je absolutní vědomí fenomenologicky vykazatelné. Ve skutečnosti Husserlův postup při zavedení absolutního vědomí - navzdory Husserlovu slovníku - de facto upomíná na transcendentální argumenty o podmínkách možnosti empirického vědomí, jimiž se vyznačoval německý idealismus. Vzhledem k tomu je otázkou, zdali Husserlův plán fenomenologie jako obratu $\mathrm{k}$ názornému popisu věcí samých nedospěl $\mathrm{v}$ řešení problému nekonečně nekonečného regresu pomocí koncepce absolutního vědomí spíše ke svému konci než ke svému východisku.

\section{Závěr}

Pokusili jsme se krátce načrtnout Brentanovu teorii časového vědomí v té verzi, v níž působila na Husserlovy přednášky. Zároveň jsme chtěli poukázat na hlubší motivace, které Brentana vedly $\mathrm{k}$ tomu, aby popřel časovou extenzi vnitřního vnímání, a na argumenty, které proti ní uvedl. Brentano pojal vědomí času jako vědomí, jehož všechny momenty jsou současné a obsažené v bodě př́ítomného nyní. Tato teze stojí v napětí s tezí, že vše reálné, včetně vědomí, musí nějakou dobu trvat a že o tomto trvání víme. Zatímco druhý bod se Brentano pokoušel (ne zcela úspěšně) vysvětlit svou teorií paměti, která nám ukazuje kontinuum minulých celků vědomí, první ponechal bez jasného ontologického založení.

V Husserlově přepracování Brentanova pojetí intencionality se z časovosti vnitřního vnímání stává podmínka konstituce objektivního času, nebot' názor (časová jednota jevového průběhu názorné danosti fenomenálního předmětu), v němž se časový objekt „odstiňuje“, se musí konstituovat jako imanentní časová jednota. Toto

${ }^{64}$ Tamtéž, s. 200. 
odstiňování lze také pojmout jako souhru dvou kontinuí časových jednot, a sice imanentního trvání proudu počitků a imanentního trvání proudu jejich pojetí. Husserl však v kritice, která zazněla v roce 1905, podcenil Brentanovu teorii. Jak výtka, že Brentano nevysvětluje konstituci časových jednot pomocí schématu obsah pojetí pojetí, tak výtka, že přítomná současnost aktů jakožto podmínka konstituce časové jednoty je dogma, si zpočátku nevšímají nebezpečí nekonečného regresu, jehož si byl Brentano vědom, a nesouladu s běžnou zkušeností vnímání. Husserl se s Brentanovým argumentem nekonečného regresu seznámil v roce 1908, což dokládá rukopis $O$ primární modifikaci paměti. Snaha tento regres vyřešit, vedla k opuštění schématu obsah pojetí - pojetí a $\mathrm{k}$ zavedení pojmu absolutního vědomí. Zároveň došlo k ostrému odlišení prríčné retencionality, v níž se spontánně konstituuje trvající proud absolutního vědomí od retence ve smyslu primární vzpomínky. Absolutní vědomí je však paradoxně nečasové či spíše předčasové, čímž se všechny jeho charakteristiky, včetně hovoru o proudu, ukazují být pouhými metaforami. Toto vědomí také nemůže být předmětem vnímání v žádném běžném smyslu a jeho dostupnost pro reflexi je nevyřešeným tématem. Společná přítomnost obsahů absolutního vědomí není $\mathrm{z}$ hlediska transcendentálního idealismu myslitelná ani jako současnost v běžném smyslu, ani jako obsaženost vědomí v aktuálním nyní času př́rody.

\section{Literatura}

Bergmann, H. (1908): Untersuchungen zum Problem der Evidenz der inneren Wahrnemung. Niemeyer, Halle.

Bernet, R. (1985): „Einleitung.“ In Texte zur Phänomenologie des ineren Zeitbewußtseins (1893-1917), E. Husserl Meiner, Hamburg, 1985.

Boehm, R. (1964): „Einleitung des Herausgebers.“ In Zur Phänomenologie des inneren Zeitbewusstseins (1893-1907), E. Husserl, Husserliana, Band X. Nijhoff, Hague, 1964.

Brentano, F. (1874): Psychologie vom empirischen Standpunkt. Duncker \& Humblot, Leipzig.

Brentano, F. (1977): Die Abkehr vom Nichtrealen. Ed. F. Mayer-Hillebrand, Meiner, Hamburg.

Brentano, F. (1976): Philosophische Untersuchungen zu Raum, Zeit und Kontinuum. Meiner, Hamburg.

Ehrenfels, Ch. (1890): „Über ,Gestaltqualitäten“ “ Vierteljahrsschrift für wissenschaftliche Philosophie 14: 242-292.

Husserl, E. (1891): Philosophie der Arithmetik. Pfeffer, Halle-Saale.

Husserl, E. (1894): „Psychologische Studien zur Elementaren Logik.“ Philosophische Monatshefte 30: 159-191. 
Husserl, E. (1901): Logische Untersuchungen. Zweiter Teil: Untersuchungen zur Phänomenologie und Theorie der Erkenntnis. Niemeyer, Halle.

Husserl, E. (1979): Aufsätze und Rezensionen (1890-1910). Husserliana, Band XII, Nijhoff, Hague.

Husserl, E. (1985): Texte zur Phänomenologie des ineren Zeitbewußtseins (1893-1917). Meiner, Hamburg.

Husserl, E. (1993): Briefwechsel, Band IV, Freiburger Schüler. Nijhoff, Hague.

Husserl, E. (1996): Přednášky k fenomenologii vnitřního časového vědomí. Přeložili V. Špalek \& W. Hansel. Ježek, Praha.

Chalmers, D. (2002): Philosophy of Mind. Classical and Contemporary Readings. Oxford University Press, Oxford.

Chisholm, R. (1981a): „Brentano“s Analysis of the Consciousness of Time.“ Midwest Studies in Philosophy 6 (1): 3-16.

Chisholm, R. (1981b) „Introduction to the Theory of Categories.“ In The Theory of Categories, F. Brentano, eds. R. Chisholm \& N. Guterman, Nijhoff, Hague, 1981.

Chrudzimski, A. (2005): Intentionalität, Zeitbewusstsein und Intersubjektivität. Studien zur Phänomenologie von Brentano bis Ingarden. Ontos, Frankfurt.

James, W. (1890): Principles of Psychology. Holt, New York.

James, W. (1895): „Presidential Adress.“ Psychological Review 2: 105-113.

Kraus, O. (1919): Franz Brentano, zur Kenntnis seines Lebens und seiner Lehre mit Beiträgen von Carl Stumpf und Edmund Husserl. Oskar Beck, München.

Kraus, O. (1930): „Zur Phänomenognosie des Zeitbewußtseins.“ Archiv für gesamte Psychologie 75 (1-2): 1-22.

Meinong, A. (1899): „Über gegenstände höherer Ordnung und deren Verhältnis zur inneren Wahrnehmung.“ Zeitschrift für Psychologie und Physiologie der Sinnesorgane 21: 182-272.

Schuhmann, K. (1977): Husserl-Chronik. Nijhoff, Hague.

Strong, C. A. (1896): „Consciousness and Time.“ Psychological Review 3: 149-157.

Twardowski, K. (1894): Zur Lehre vom Inhalt und Gegenstand der Vorstellungen. Hödler, Wien. 